\title{
Analytical characteristics of olive oils produced by two different extraction techniques, in the Portuguese olive variety 'Galega Vulgar'
}

\author{
By Luís Vaz-Freire ${ }^{a}$, José Manuel J. Gouveia ${ }^{b}$ and Ana Maria Costa Freitas ${ }^{a *}$
}

\author{
aDepartamento de Fitotecnia, Instituto de Ciências Agrárias e Mediterrânicas, \\ Universidade de Évora, Apt 94, 7002-554 Évora, PORTUGAL (*afreitas@uevora.pt) \\ ${ }^{b}$ Departamento de Agro-Indústrias e Agronomia Tropical, Instituto de Agronomia \\ Universidade Técnica de Lisboa, Tapada da Ajuda, 1349-017 Lisboa, Portugal
}

\section{RESUMEN}

Características analíticas de los aceites de oliva producidos por diversas técnicas de extracción con la variedad portuguesa 'Galega Vulgar'.

Se han comparado dos líneas de procesamiento de aceite, utilizando un sistema de prensas (SP) o un decantador centrífugo (DC). El procesamiento que recurre al sistema de prensas es un sistema discontinuo que, sin embargo permite obtener aceites vírgenes de gran calidad. Para este estudio se ha utilizado la variedad Portuguesa Galega común. Las aceitunas fueron tratadas contra el ataque de plagas, y recogidas en un punto de maduración predeterminado. Del mismo modo, se evaluó el porcentaje de aceite obtenido de la cosecha. Se han considerado los resultados analíticos teniendo en cuenta la determinación de la influencia de la extracción en el producto final. Este punto ha sido evaluado por medio de un tratamiento estadístico. Aunque se han observado diferencias significativas entre los resultados de algunos de los parámetros analizados, sólo las diferencias verificadas en el grado de acidez son susceptibles de modificar la clasificación final del aceite, situándolo en la categoría lampante.

PALABRAS CLAVE: Aceite de oliva - 'Galega Vulgar' Técnicas de extracción - Tecnología.

\section{SUMMARY}

Analytical characteristics of olive oils produced by two different extraction techniques, in Portuguese olive variety 'Galega Vulgar'.

A metal hammer-decanter (HD) olive processing line was compared to a traditional metal hammer-press (HP) line, a discontinuous method which, when properly used, yields high-quality virgin olive oils. Galega olives (traditional Portuguese variety) were used. Olives were picked at a predetermined maturation stage and plagues and oil content were evaluated before processing. Years, extraction technology, data replicates, and years* extraction, were taken into account and compared using statistical treatment. In spite of significant differences among the results obtained, only acidity was statistically significant and sufficient for classifying the produced olive oil into a lampante category.

KEY-WORDS: Extraction technique - 'Galega Vulgar' Olive oil - Technology.

\section{INTRODUCTION}

Olive trees belong to the Olea europea $L$. family but among them different cutivars with different characteristics can be found in the world's production areas. The most important cultivars used in Portugal are Galega Vulgar, Carrasquenha, Cordovil, Cobrançosa and Verdeal (Gouveia, 1995; Bartolini et al., 1998). Portuguese cultivars with a major interest in the olive oil industry are those responsible for the olive oils of Protected Denomination Origins (DOP) (Bartolini et al., 1998; Gouveia et al., 2002), where the predominant variety is Galega Vulgar, representing $80 \%$ of the olive patrimony in Portugal (Gemas et al., 2002).

In general terms, olive oil quality is related to olive ripeness, olive sanitary condition and processing but also to origin, variety and storage. (Vinha et al., 2005; Torres et al., 2006). Processing is, in fact, a major factor affecting olive oil quality. Pressed oil obtained under the proper processing conditions is usually of great quality. Press extraction was almost the only olive oil extraction process used for centuries. However, Olive oil processing has progressed significantly since the beginning of the seventies, when the centrifugation system appeared. Since then, many articles comparing the so-called three-phase centrifugation extraction system with the two-phase centrifugation system (Vlyssides et al., 2004) have been written. When compared to the press system these processes are sometimes regarded as producing olive oils of inferior quality (Rannalli et al., 2001). To verify olive oil characteristics, chemical and sensorial analyses can be used. Several studies have been carried out comparing aroma compounds, oxidative stability, phenolic compounds, color and other chemical parameters (Boskou, 1996; Ranalli et al., 1997; Aparicio and Luna, 2002).

In this work olive oil produced by two different extraction technologies, decanter and pressing by hydraulic press, were evaluated, by means of routine regulated analyses. The results obtained were evaluated in order to verify if differences could be significant for placing the olive oil in different classifications. If different classified olive oils were obtained we could conclude that not only the intrinsic quality was affected but also its commercial value. Technological studies similar to this can provide important information to determine not only 
the differences among the produced olive oils but also to improve technology .

\section{MATERIALS AND METHODS}

\subsection{Sampling}

Experiments were carried out by processing mechanically picked olives from the Portuguese cultivar Galega Vulgar under defined conditions. All olives were picked under proper, controlled sanitary conditions. Olives were picked during the harvests of 2001, 2002, 2003 and 2004. A $120 \mathrm{Kg}$ sample was collected. Fruits were stored in open boxes at ambient temperature $\left(5-15^{\circ} \mathrm{C}\right)$ with reasonable air flow and without direct light incidence. Extraction was made during the next 24h. Before extraction, leaves and dirt (soil, stones, etc) were removed by washing under cold running water.

Maturation index was determined according to Hermoso et al. (1991). Fat yield and humidity percentage were also determined before extraction. For these olives the percentage of Gloeosporium olivarum Alm. or Dacus oleae Rossi (olive fly) attack was determined by visual inspection. Three replicates for each extraction procedure (pressing and centrifugation) were made for each collected sample with the exception of the 2001 harvest, where only two replicates were made due to severe climatic conditions.

\subsection{Extraction technology}

A homogeneous $20 \mathrm{Kg}$ sample was processed (each time) for each one of the technologies under study: a hammer-mill press line (Vieirinox, Portugal) and a hammer-mill integral decanter line (Oliomio, Italy) were used. No water was added to the olive paste in both systems and malaxing time, about 1 $\mathrm{h}$, was equal for both methods. For the pressing system the liquid-liquid separation was made by natural process, decantation. Three replicates were made for each extraction process.

\subsection{Olive Oil Analysis}

Acidity was determined according to the EC regulation no 2568/91 annex II, Spectrofotometry UV absorption was made according to the EC regulation no 2568/91 annex IX; Peroxide value followed the EC regulation ํㅡ 2568/91 annex III; Rancidity was analyzed according to the Portuguese norm NP 4158 de 1991; Sterols, uvaol and eritrodiol were in accordance with the EC regulation $n^{\circ}$ 2568/91 annex V; fatty acids with the EC regulation $n^{\circ}$ 2568/91 annex XB; waxes with the EC regulation no 2568/91 annex IV and triglycerides with the EC regulation no 2568/91 anexe VIII.

For Polyphenol analyses, a procedure developed at Instituto Superior de Agronomia, based on the Folin Ciocalteu's method, was followed (internal proceeding IT065, Lab. de Estudos Técnicos, ISA, UTL. Lisboa Portugal),

Tocopherols were determined according to the method described by P. Rovellini et al. (1997), which uses High Performance Liquid Chromatography; connected to an ultraviolet detector (HPLC-UV).

\subsection{Statistics}

For the ANOVA, General Linear model analysis the software used was the Minitab version 12 for Windows (Minitab Inc., State College, USA).

\section{RESULTS AND DISCUSSION}

Tables 1 and 2 show the homogeneity of the samples in terms of maturation, fat content, humidity and dry matter. According to the results in Table 1 we might consider that harvesting was carried out at similar maturation stages. The same

Table 1

Results of maturation index for 2002, 2003 e 2004

\begin{tabular}{|c|c|c|c|}
\hline & & \multicolumn{2}{|c|}{ Olive (Galega V..) } \\
\hline \multicolumn{2}{|c|}{2002} & \multicolumn{2}{|c|}{4,6} \\
\hline \multicolumn{2}{|c|}{2003} & \multicolumn{2}{|c|}{4,7} \\
\hline \multicolumn{2}{|c|}{2004} & \multicolumn{2}{|c|}{4,5} \\
\hline \multicolumn{2}{|c|}{ Median } & \multicolumn{2}{|c|}{4,6} \\
\hline \multicolumn{2}{|c|}{ RSD } & \multicolumn{2}{|c|}{0,1} \\
\hline \multicolumn{2}{|c|}{$\begin{array}{l}\text { Relative Standard } \\
\text { Deviation (\%) }\end{array}$} & \multicolumn{2}{|c|}{1,7} \\
\hline \multicolumn{4}{|c|}{$\begin{array}{l}\text { Table } 2 \\
\text { Results from RMN tests for fats and humidity }\end{array}$} \\
\hline & Humidity \% & Fat-RMN & $\begin{array}{l}\text { \% of fat in } \\
\text { dry matter }\end{array}$ \\
\hline $\begin{array}{l}\text { Median } \\
2002(n=3)\end{array}$ & 43,90 & 27,28 & 48,63 \\
\hline $\begin{array}{l}\text { Median } \\
2003(n=3)\end{array}$ & 46,38 & 24,04 & 44,83 \\
\hline $\begin{array}{l}\text { Median } \\
2004(n=3)\end{array}$ & 46,00 & 21,85 & 40,46 \\
\hline $\begin{array}{l}\text { Median of } \\
\text { Medians }\end{array}$ & 45,43 & 24,39 & 44,64 \\
\hline SD & 1,33 & 2,73 & 4,09 \\
\hline RSD (\%) & 2,94 & 11,20 & 9,16 \\
\hline
\end{tabular}


can be stated as far as humidity percentage is concerned but not for the fat content. In fact, for fat content a standard deviation of 11.20 was obtained.

The results obtained for pest control Gloeosporium olivarum Alm. or Dacus oleae Rossi (olive fly) show a significant difference among years (Table 3). These verified differences, although acceptable, cannot be explained by climate conditions (rain) since 2004 was dryer than 2003.
On the other hand, the sanitary state observed in each of the studied years may justify the difference verified for fat content (Boskou, 1996; Barranco et al., 2001), since this plague definitely affects olive oil quality and is, in Portugal, quite difficult to control if a severe attack occurs .

For olive oil results (Tables 4-8) we might consider that most data, for all studied parameters, lie in the legal intervals considered for extra virgin olive oil

Table 3

Pests control Gloeosporium olivarum Alm. (G) and Dacus oleae Rossi (Fly), for variety Galega Vulgar.

\begin{tabular}{lccccc}
\hline & Olive Fly in \% & $\begin{array}{c}\text { Olive Fly with } \\
\text { deposition in \% }\end{array}$ & Fly in \% & G in \% & Infested Olives (\%) \\
\hline 2003 & 0,3 & 0,0 & 0,3 & 6,0 & 6,3 \\
2004 & 10,0 & 2,0 & 13,0 & 60,0 & 76,1 \\
Media & 5,6 & 1,5 & 7,1 & 31,6 & 40,5 \\
SD & 6,5 & 1,1 & 7,6 & 40,5 & 50,5 \\
RSD \% & 116,1 & 71,0 & 106,5 & 127,9 & 124,7 \\
\hline
\end{tabular}

Table 4

Results for the fatty acids content during studied harvests in both extraction systems used

\begin{tabular}{ccccccccc}
\hline Year & $\mathbf{2 0 0 1}$ & $\mathbf{2 0 0 1}$ & $\mathbf{2 0 0 2}$ & $\mathbf{2 0 0 2}$ & $\mathbf{2 0 0 3}$ & $\mathbf{2 0 0 3}$ & $\mathbf{2 0 0 4}$ & $\mathbf{2 0 0 4}$ \\
\hline $\begin{array}{c}\text { Extraction } \\
(\mathbf{n}=\mathbf{3})\end{array}$ & 2 Phases & Press & 2 Phases & Press & 2 Phases & Press & 2 Phases & Press \\
\hline C14:0 (\%) & 0,01 & 0,01 & 0,01 & 0,01 & 0,01 & 0,01 & 0,01 & 0,01 \\
C16:0 (\%) & 14,85 & 14,18 & 14,55 & 14,33 & 14,19 & 14,70 & 14,25 & 13,80 \\
C16:1 (\%) & 2,91 & 2,25 & 2,03 & 1,85 & 1,99 & 1,79 & 2,06 & 1,76 \\
C17:0 (\%) & 0,11 & 0,10 & 0,12 & 0,04 & 0,11 & 0,08 & 0,12 & 0,09 \\
C17:1 (\%) & 0,30 & 0,25 & 0,31 & 0,29 & 0,30 & 0,19 & 0,32 & 0,22 \\
C18:0 (\%) & 1,55 & 2,05 & 1,84 & 2,26 & 1,79 & 2,08 & 1,90 & 2,08 \\
C18:1 (\%) & 73,60 & 73,05 & 75,89 & 74,13 & 75,19 & 73,29 & 76,08 & 74,29 \\
C18:2 (\%) & 5,07 & 6,46 & 3,93 & 5,68 & 5,04 & 6,43 & 3,91 & 6,33 \\
C20:0 (\%) & 0,33 & 0,37 & 0,30 & 0,33 & 0,31 & 0,34 & 0,30 & 0,33 \\
C18:3 (\%) & 0,83 & 0,83 & 0,69 & 0,74 & 0,72 & 0,71 & 0,64 & 0,67 \\
C20:1 (\%) & 0,28 & 0,28 & 0,23 & 0,22 & 0,24 & 0,23 & 0,27 & 0,27 \\
C22:0 (\%) & 0,10 & 0,12 & 0,08 & 0,09 & 0,08 & 0,10 & 0,09 & 0,10 \\
C24:0 (\%) & 0,05 & 0,06 & 0,04 & 0,04 & 0,03 & 0,05 & 0,04 & 0,05 \\
Trans C16:1 (\%) & 0,12 & 0,12 & 0,11 & 0,11 & 0,11 & 0,11 & 0,10 & 0,09 \\
Trans C18:1 & 0,01 & 0,03 & 0,02 & 0,02 & 1,16 & 0,02 & 0,01 & 0,02 \\
\hline Trans C18:2 (\%) & 0,03 &
\end{tabular}


Table 5

Results for waxes content during studied harvests in both extraction systems used

\begin{tabular}{ccccccc}
\hline Year & $\begin{array}{c}\text { Extraction } \\
(\mathbf{n}=\mathbf{3})\end{array}$ & $\begin{array}{c}\mathbf{C ~ 4 0} \\
(\mathbf{m g} / \mathbf{k g})\end{array}$ & $\begin{array}{c}\mathbf{C ~ 4 2} \\
(\mathbf{m g} / \mathbf{k g})\end{array}$ & $\begin{array}{c}\mathbf{C ~ 4 4} \\
(\mathbf{m g} / \mathbf{k g})\end{array}$ & $\begin{array}{c}\mathbf{C ~ 4 6} \\
(\mathbf{m g} / \mathbf{k g})\end{array}$ & $\begin{array}{c}\text { Total Wax } \\
(\mathbf{m g} / \mathbf{k g})\end{array}$ \\
\hline 2001 & 2 Phases & 28,40 & 39,63 & 34,56 & 25,84 & 128,43 \\
2001 & Press & 25,67 & 36,38 & 30,22 & 22,01 & 114,28 \\
2002 & 2 Phases & 11,36 & 20,07 & 8,83 & 10,18 & 50,43 \\
2002 & Press & 13,87 & 19,13 & 10,18 & 12,45 & 55,63 \\
2003 & 2 Phases & 6,94 & 12,65 & 8,36 & 12,91 & 40,85 \\
2003 & Press & 23,75 & 32,24 & 29,14 & 35,15 & 120,28 \\
2004 & 2 Phases & 10,12 & 18,20 & 9,04 & 13,88 & 51,24 \\
2004 & Press & 15,96 & 21,94 & 21,44 & 16,42 & 75,76 \\
\hline
\end{tabular}

Table 6

Results for triacylglycerols content during studied harvests in both extraction systems used

\begin{tabular}{lcccccccc}
\hline \multicolumn{1}{c}{ Year } & $\mathbf{2 0 0 1}$ & $\mathbf{2 0 0 1}$ & $\mathbf{2 0 0 2}$ & $\mathbf{2 0 0 2}$ & $\mathbf{2 0 0 3}$ & $\mathbf{2 0 0 3}$ & $\mathbf{2 0 0 4}$ & $\mathbf{2 0 0 4}$ \\
\hline Extraction (n=3) & 2 Phases & Press & 2 Phases & Press & 2 Phases & Press & 2 Phases & Press \\
\hline LLL & 0,06 & 0,09 & 0,04 & 0,11 & 0,21 & 0,09 & 0,09 & 0,07 \\
OLLn & 0,31 & 0,30 & 0,32 & 0,43 & 0,14 & 0,26 & 0,14 & 0,25 \\
PLLn & 0,09 & 0,11 & 0,03 & 0,07 & 0,05 & 0,07 & 0,09 & 0,11 \\
OLL & 0,81 & 1,42 & 0,44 & 1,21 & 0,50 & 1,38 & 0,46 & 1,31 \\
OOLn & 2,19 & 2,09 & 1,24 & 1,50 & 1,64 & 1,61 & 1,72 & 1,46 \\
PoOL & 0,97 & 0,85 & 0,00 & 0,29 & 0,68 & 0,64 & 0,00 & 0,39 \\
PLL & 0,00 & 0,00 & 1,02 & 0,70 & 0,00 & 0,22 & 0,75 & 0,76 \\
POLn & 0,13 & 0,15 & 0,34 & 0,12 & 0,11 & 0,12 & 0,15 & 0,14 \\
OOL+LnPP+PoOO & 12,21 & 13,07 & 10,05 & 11,35 & 10,16 & 12,43 & 10,06 & 12,08 \\
POL+StLL & 6,04 & 6,56 & 4,65 & 5,71 & 4,84 & 6,00 & 5,08 & 6,49 \\
PPoO+PPL & 0,85 & 1,05 & 0,84 & 0,96 & 0,89 & 0,79 & 1,04 & 1,13 \\
OOO & 38,98 & 38,54 & 43,54 & 40,70 & 43,57 & 40,65 & 42,14 & 39,12 \\
POO & 28,22 & 26,47 & 28,40 & 26,98 & 27,68 & 26,20 & 28,62 & 27,20 \\
PPO & 4,80 & 4,30 & 4,56 & 4,42 & 4,51 & 4,21 & 4,55 & 4,34 \\
PPP & 0,32 & 0,17 & 0,10 & 0,24 & 0,25 & 0,20 & 0,16 & 0,13 \\
StOO+StOSt & 3,04 & 3,68 & 3,59 & 3,97 & 3,53 & 3,80 & 3,54 & 3,74 \\
PStO & 0,86 & 0,94 & 0,85 & 1,12 & 1,03 & 1,06 & 0,97 & 0,98 \\
PPSt & 0,12 & 0,20 & 0,30 & 0,12 & 0,20 & 0,23 & 0,44 & 0,29 \\
\hline
\end{tabular}


Table 7

Results for polyphenols e tocopherols content during studied harvests in both extraction systems used

\begin{tabular}{ccccc}
\hline Year & $\begin{array}{c}\text { Extraction } \\
(\mathbf{n}=\mathbf{3})\end{array}$ & Polyphenols & $\gamma$ Tocopherols & $\alpha$ Tocopherols \\
\hline 2001 & 2 Phases & 21,99 & 27,30 & 281,67 \\
2001 & Press & 17,83 & 23,99 & 239,14 \\
2002 & 2 Phases & 42,77 & 11,36 & 215,77 \\
2002 & Press & 64,54 & 14.92 & 244,56 \\
2003 & 2 Phases & 80,45 & 8,69 & 201,49 \\
2003 & Press & 110,92 & 14,06 & 246,12 \\
2004 & 2 Phases & 64,12 & 19,00 & 260,66 \\
2004 & Press & 39,64 & 16,26 & 198,94 \\
\hline
\end{tabular}

Table 8

Results for sterols content during studied harvests in both extraction systems used

\begin{tabular}{ccccccccc}
\hline Year & $\mathbf{2 0 0 1}$ & $\mathbf{2 0 0 1}$ & $\mathbf{2 0 0 2}$ & $\mathbf{2 0 0 2}$ & $\mathbf{2 0 0 3}$ & $\mathbf{2 0 0 3}$ & $\mathbf{2 0 0 4}$ & $\mathbf{2 0 0 4}$ \\
\hline Extraction $(\mathbf{n}=\mathbf{3})$ & Press & 2 Phases & Press & 2 Phases & Press & 2 Phases & Press & 2 Phases \\
\hline Cholesterol & 0,24 & 0,33 & 0,12 & 0,12 & 0,17 & 0,25 & 0,14 & 0,22 \\
Campesterol & 1,71 & 3,15 & 2,75 & 2,82 & 2,76 & 2,7 & 2,94 & 2,87 \\
Stigmasterol & 0,93 & 1,56 & 1,57 & 1,4 & 1,29 & 0,6 & 0,62 & 0,92 \\
apparent $\beta$-sitosterol & 93,44 & 93,84 & 94,34 & 94,52 & 94,72 & 95,43 & 95,19 & 94,86 \\
$\Delta$ - 7 - stigmasterol & 0,16 & 0,17 & 0,18 & 0,16 & 0,24 & 0,2 & 0,19 & 0,22 \\
Eritrodiol + Uvaol & 1,21 & 1,46 & 1,85 & 1,83 & 1,74 & 1,07 & 1,08 & 1,56 \\
Total Sterols & 2508,4 & 2115,8 & 1545,59 & 1595,95 & 1588,7 & 1503,67 & 1672,25 & 1619,08 \\
\hline
\end{tabular}

classification with one exception. For the olive oil obtained from the Press system the acidity value is above 2 in the last three years of analysis and therefore the resulting oil should be classified as "lampante" olive oil (Regulation CE nำ1989/2003). These results are hard to understand since acidity with press extraction is usually not affected but, in this case, it was obtained in three of the studied years and so it is most likely related to the system used.

The above assumptions were taken only from an analytical point of view and were not based on any statistical treatment. To allow reliable conclusions an ANOVA treatment was applied. Extraction technologies as well as replicates were the target variable. The interaction extraction*replicates were also tested. The statistical analysis was made using the software Minitab the ANOVA General Linear Model, with a significance level of $95 \%$. In Table 9 only the interactions where significant differences were detected are presented. From this table we could conclude that data replicates did not show significant differences, with an exception in acidity values, probably due to prolonged contact with water coming from the separation process, which occurs when the pressing technology is used. The separation time is also longer when the press system is used which might also account for the differences observed.

As can be observed, extraction technology has had a significant impact on some of the data obtained.

For sterols analysis, extraction technology has a significant impact on the results only for the Uvaol+Eritrodiol and total sterols. The slight differences verified in individual data (table 8) are common in the same variety (Alves et al., 2005). 
For fatty acids (Table 4) only the heptadecenoic acid $(C 17: 1)$ presents results beyond regulation limits for extra virgin olive oils. These values were detected for only one extraction system (two phase decanter) although only in the year 2004, but if we considered the covariance for the heptadecenoic acid (C17:1), we verify that it is not higher than $5 \%$ for the highest permitted value according to regulation (Regulation (CE) no 1989/2003). In Table 4, trans-palmitoleic acid is also above the regulated value for all the oils, however, when this value is considered in combination with trans-linolenic acid the final value falls within the allowed range for extra virgin olive oil.
In Table 9 significant differences, due to extraction system are shown for C16:1, C17:0, C17:1, C18:1, C18:2, C20:0 e C18:3 acids.

Table 5 shows significant differences for the C40, C42, C44 as well as for Total Wax content, however Total Wax is always $<250 \mathrm{mg} / \mathrm{kg}$, thus the resulting oils can always be classified as extra virgin.

For the triacylglycerols the impact of the extraction procedure was significant for some data (PoOL, OOL+LnPP, POL+StLL, OOO, POO, PPO and StOO+StOSt) (Table 6). These results are in accordance with others previously reported, in which, in addition to cultivar, other rather important

Table 9

Results of the application of ANOVA General Linear Model, Software Minitab, with a significance level of $95 \%$, the analytical data collected. (Replicates and extraction technology were the variables)

\begin{tabular}{|c|c|c|c|c|}
\hline & Source & DF & $\mathbf{F}$ & $\mathbf{P}$ \\
\hline & Extraction & 1 & 155,53 & 0,003 \\
\hline \multirow[t]{2}{*}{ Acidity \% } & Repetition & 2 & 4,87 & 0,028 \\
\hline & Extraction*Repetition & 2 & 3,92 & 0,047 \\
\hline K232 (Abs.) & Extraction & 1 & 25,39 & 0,003 \\
\hline K270 (Abs.) & Extraction & 1 & 5,48 & 0,038 \\
\hline IP (mEq O2/kg) & Extraction & 1 & 17,97 & 0,004 \\
\hline \multirow[t]{2}{*}{ Cholesterol } & Extraction*Repetition & 2 & 6 & 0,016 \\
\hline & Extraction & 1 & 18,06 & 0,004 \\
\hline Stigmasterol & Extraction*Repetition & 2 & 4,13 & 0,042 \\
\hline Uvaol+Eritrodiol & Extraction & 1 & 54,78 & 0,003 \\
\hline Total Sterols & Extraction & 1 & 24,53 & 0,003 \\
\hline C16:1 & Extraction & 1 & 17,3 & 0,001 \\
\hline C17:0 & Extraction & 1 & 5,73 & 0,037 \\
\hline C17:1 & Extraction & 1 & 6,76 & 0,026 \\
\hline C18:0 & Extraction & 1 & 41,02 & 0,003 \\
\hline C18:1 & Extraction & 1 & 14,58 & 0,005 \\
\hline C18:2 & Extraction & 1 & 15,39 & 0,005 \\
\hline C20:0 & Extraction & 1 & 8,38 & 0,016 \\
\hline C18:3 & Extraction & 1 & 7,34 & 0,022 \\
\hline OLLn & Extraction & 1 & 14,96 & 0,005 \\
\hline OLL & Extraction & 1 & 42,1 & 0,003 \\
\hline PoOL & Extraction & 1 & 55,85 & 0,003 \\
\hline OOL+LnPP & Extraction & 1 & 29,34 & 0,003 \\
\hline POL+StLL & Extraction & 1 & 34,96 & 0,003 \\
\hline 000 & Extraction & 1 & 30,19 & 0,003 \\
\hline POO & Extraction & 1 & 49 & 0,003 \\
\hline PPO & Extraction & 1 & 25,9 & 0,003 \\
\hline StOO+StOSt & Extraction & 1 & 21,39 & 0,004 \\
\hline \multirow[t]{2}{*}{ Polyphenols } & Extraction & 1 & 6,22 & 0,031 \\
\hline & Repetition & 2 & 1,83 & 0,205 \\
\hline
\end{tabular}


factors affecting total fatty acid composition, and especially oleic acid content include latitude, climatic conditions, and the ripening stage of the fruit at harvest (Ranalli et al., 1997; Aparicio and Luna, 2004, Aranda et al., 2004) as well as extraction method (Salvador et al., 2001).

\section{CONCLUSIONS}

From these results we can conclude that extraction methods might be responsible for some of the differences observed in olive oil quality since, for the same raw material, different final products are obtained. Taking into account the olive oil classification from EC Regulation № 1989/2003 from November $6^{\text {th, }}$ it is clear, however, that besides acidity, all the significant differences among the parameters studied are not sufficient to change the oil classification. Acidity differences are enough to depreciate the oil in terms of classification. The high acidity obtained for the oil from press extraction is probably due to an extreme hydrolysis of fat due to the excessive contact time of the oil with vegetation water during the decanting step.

\section{ACKNOWLEDGEMENTS}

Fundação para a Ciência a e Tecnologia MCTES; Projecto Agro 824 - MADRP.

\section{REFERENCES}

Alasalvar C, Shahidi F, Ohshima T, Wanasundara U, Yurttas HC, Liyanapathirana CM, Rodrigues FB. 2003. Turkish Tombul Hazelnut. 2. Lipid characteristics and oxidative stability. J. Agric. Food Chem. 51, 3797-3805.

Alves MR, Cunha SC, Amaral JS, Pereira JA, Oliveira MB. 2005. Classification of PDO olive oils on the basis of their sterol composition by multivariate analysis. Anal. Chimica Acta 549, 166-178

Aparicio R, Luna G. 2002. Characterization of monovarietal virgin olive oils. Eur. J. of Lipid Sc. and Technology, 104, 614-627.

Aranda F, Gómez-Alonso S, Rivera del Alamo RM, Salvador MD, Fregapane G. 2004. Triglyceride, total and 2-position fatty acid composition of Cornicabra virgin olive oil: Comparison with other Spanish cultivars. Food Chem. 86, 485-492.

Barranco A, Fernández-Escobar R, Rallo L. 2001. El cultivo del olivo. Junta de Andalucia \& Mundi Prensa, Andalucia, España.

Bartolini G, Prevost G, Messeri C, Carignani G, Menini U.G. 1998. Olive Germoplasm. Cultivars and WorldWide Collections. FAO, Rome.

Boskou D. 1996. Olive oil. Chemistry and Technology. AOCS Press, Illinois, USA.
EC Regulation n²568/1991 annex II - Determination of the free fatty acids.

EC Regulation no2568/1991 annex III - Determination of the peroxide value.

EC regulation nำ568/1991 annex IV - Determination of waxes.

EC regulation n2568/1991 annex $V$ - Determination of sterols.

EC regulation nำ2568/1991 annex VIII - Determination of triglycerides.

EC Regulation no2568/1991 annex IX Spectrophotometric investigation in the ultraviolet.

EC regulation n-2568/1991 annex XB - Determination of fatty acids.

EC Regulation $\mathrm{n}-1989 / 2003$ of 6 of November amending Regulation (EEC) No 2568/1991 on the characteristics of olive oil and olive-pomace oil and on the relevant methods of analysis

Gemas VJV, Rijo-Johansen MJ, Fevereiro P. 2002. IntraVariability of the Portuguese Olive Cultivar Galega Vulgar expressed by RAPD, ISSR and SPAR. ISHS Acta Horticulturae 586, 175-178.

Gouveia JMB. 1995. Azeites Virgens do Alto Alentejo. Comportamento Químico, Tecnológico e Sensorial. Universidade Técnica de Lisboa, Instituto Superior de Agronomia, Lisboa.

Gouveia J, Saldanha J, Martins A, Modesto M, Sobral V. 2002. O Azeite em Portugal, Edições Inapa, Portugal

Hermoso M, Uceda M, Garc,a A, Morales B, Frias ML, Fernandez A. 1991. Elaboracion de aceite de calidad. Consejeria de Agricultura y Pesca, Serie Apuntes, 5/92, Sevilla.

IT065 - 2004. Polyphenols analyses internal proceeding. Lab. de Estudos Técnicos, ISA, UTL. Lisboa, Portugal

Portuguese Norm NP 4158 de 1991 - Edible fat and oils. Determination of oxidative stability.

Ranalli A, de Mattia G, Ferrante ML, Giansante L. 1997. Incidence of olive cultivation area on the analytical characteristics of the oil. Note 1. Riv. Ital. Sostanze Grasse 74, 501-508.

Rovellini P, Azzolini M, Cortesi N. 1997. Tocoferoli e tocotrienoli in oli e grassi vegetali mediante HPLC. Riv. Ital. Sostanze Grasse 74, 1-5.

Salvador MD, Aranda F, Gómez-Alonso S, Fregapane G. 2001. Cornicabra virgin olive oil: a study of five crop seasons. Composition, quality and oxidative stability. Food Chem. 74, 267-274

Torres MM, Maestri DM. 2006. The effects of genotype and extraction methods on chemical composition of virgin olive oils from Traslasierra Valley (Córdoba, Argentina). - Food Chem. 96 (4), 507-511.

Vinha AF, Ferreres F, Silva BM, Valentão P, Gonçalves A, Pereira JA, Oliveira MB, Seabra RM, Andrade PB. 2005. Phenolic profiles of Portuguese olive fruits (Olea europaea L.): Influences of cultivar and geographical origin. Food Chem. 89, 561-568.

Vlyssides AG, Loizides M, Karlis PK. 2004. Integrated strategic approach for reusing olive oil extraction, byproducts. J. of Cleaner Production 12, 603-611.

Recibido: $31 / 7 / 07$ Aceptado: 19/2/08 